\title{
Service Learning on Cultural Inclusive Design for Urban Migrants' Villages: Producing Transportable Toilet
}

\author{
Obed Bima Wicandra ${ }^{1, *}$, Gunawan Tanuwidjaja ${ }^{2}$, Michaela Bella Hoesny $^{2}$, \\ Monalisa Soetrisno ${ }^{2}$, Erandaru $^{1}$, Linda Oktavia $^{3}$, and Gatot Subroto ${ }^{4}$ \\ ${ }^{1}$ Visual Communication Design Program, Faculty of Art and Design, Petra Christian University, \\ Jl. Siwalankerto No.121-131, Surabaya 60236, Indonesia \\ ${ }_{2}^{2}$ Architecture Program, Faculty of Civil and Planning, Petra Christian University, Jl. Siwalankerto \\ No.121-131, Surabaya 60236, Indonesia \\ ${ }^{3}$ Architecture Department, Faculty of Architecture and Design, Duta Wacana Christian University, \\ Jl. Dr. Wahidin Sudirohusodo No.5 - 25, Kotabaru, Daerah Istimewa Yogyakarta 55224, Indonesia \\ ${ }^{4}$ Surabaya Riverside-Villages' Residents Association (PWSS/ Paguyuban Warga Strenkali Surabaya), \\ Gunungsari II Sawahan 69, Surabaya 60223, Indonesia
}

\begin{abstract}
Adaptive-inclusive toilet design strategy was needed to respond the local unique toileting culture of Surabaya people, especially the urban migrants. The urban migrants in Surabaya live insecurely/unsafely in the slums because of the potential of Kampung's eviction/demolition. Because of their limited economic condition and anxieties about sustainable land occupation, they constructed temporary shelters from the recycled materials. To answer the needs of the migrants' sanitation, an inclusive portable toilet was produced based on the design principles and their toileting culture. The project involved several steps such as literature review, interview and photo documentation, socialization of healthy toileting culture, participative design workshop, and design development. The program was related to UNDK and supported by UBCHEA grant
\end{abstract}

Key words: Accessibility, cultural, inclusive design, toileting

\section{Introduction}

\subsection{Introduction}

The University Network of Digital [Local] Knowledge (UNDK) (http://undk.asia); a network of universities in Indonesia which aim at mainstreaming the local knowledge preservation(and equip it with digital tools \& resources); is producing a mini project to

\footnotetext{
*Corresponding author: gunte@petra.ac.id gunteitb2012@gmail.com
} 
explore local culture, supported by United Board of Christian Higher Education Association (UBCHEA) (http:// undk.asia/). Toileting culture was found as interesting issue and it also directly correspond to the important issue of the health of Surabaya people, therefore it was studied [1].

These urban migrants are found living in the informal riverside kampungs (urban villages) of Surabaya. They are migrating from rural areas of East Java Province, they came to Surabaya tosearch for opportunity for a better living by working (mostly) as unskilled workers. Because of Surabaya's increasing land value and the urban migrants' limited earnings, it's impossible for them to liveneither in the formal residentials nor the legal kampungs. Therefore, they are forced to live in the riverside slums. On the other hand, they play a very important role in the city as urban informal workers such as becak (pedicab) riders, street hawkers and train station/traditional market porters. This situation becomean irony of urban migrants' phenomenon in Surabaya.

Furthermore, the urban migrants are living insecurely/unsafely in the slum because of the potential of kampung eviction/demolition. Because of the limited economic condition and anxieties about sustainable land occupation, they constructed temporary shelters from recycled materials. Thus, the existence of transportable toilets becomes necessary. It was the rationale of the transportable facilities, such as, toilets are needed for the Kampung residents.

\subsection{Literature Review}

Universal Design Standards, Inclusive Design and also Collaborative or Co-Design were discussed in several papers by Persson, et.al.[2]; Bühler [3]; and Pirinen [4] as the methods to produce a more inclusive design in Architecture. These theories were later translated into the guiding principles of the Service Learning

Greed [5] found the toileting as an important aspect in human live. The provision of public toilets had to be considered regarding some issues, such as crime and vandalism; sexuality; the environment, water conservation and sustainability; health, hygiene and medicine; women's issues, childcare, breastfeeding and sanitary protection disposal (menstrual hygiene management); disability and ageing; architecture, engineering and design; sewerage, drainage and plumbing; religion, culture and taboo. Therefore, the design should be started with social observation and later with participatory process. These were also supported by Lanjouw, et.al [6] and Michael [7].

Meanwhile, Cummings described the close relationship between bathroom and crosscultural interaction, ethnographic experience, as well as cultural commensurability. In the bathroom, cultural background of the user would determine the acceptability of the toilet design [8].

The portable toilet was prescribed by H. Factura, et al. [9] as the Terra Preta Sanitation system. Later on K. Kindstedt adopted it for a Design of a Portable Ecological Sanitation Toilet for Disaster Relief [10]. A portable toilet for disaster response was prescribed. The urine and the fecal were separated. The feces were treated with lacto-fermentation process. Further, Biochar was added to eliminate odor and changed the excreta to a soil additive. The paper actually showsthe possibility to create healthy and portable toilet design.

\section{Methodology}

Ammount nine lecturers and 325 students from three Programs/Departments (Architecture, Visual Communication Design and English Literature) in Petra Christian University were involved in the UNDK Mini Project, "Portraying the Toileting Culture of Surabaya People: People's Perception and Toilet Design Diversity", in 2013 
The project's goals were to find a number Surabaya's toilet users in several locations (in the scope), to find and to document their toileting behaviour, to find the types of the available toilets in Surabaya (in the Residential and Kampung Settlement, Public Toilets and Private Toilets), to produce comics or illustration about the diverse healthy toileting in Surabaya, and eventually to find the design strategy to provide locally friendly yet also healthy and accessible toilets.

Several products were produced in the program such as the documentation of the Toileting Culture (interview, sketches, photo documentation, google-map and banner), video of the Toileting Culture, theatre performance symbolizing the Toileting Culture and design Model of Inclusive Toilet for Indonesian. The outcome of this project was a community outreach program on healthy toileting program in several riverside villages in Surabaya during 2014 to 2015. Another need for portable toilet was also found and designed.

The project involved several steps such as literature review, interview and photo documentation, socialization of healthy toileting culture, participative design workshop, and design development.

The Literature Review was conducted to understand the importance of toileting culture and toileting needs especially on the design aspect. Actually two toilet design projects were chosen, which were the toilet in a school for thevisually impaired and a toilet in the riverside village. The paper discussed the portable toilet design for riverside.

Toileting culture exploration was conducted by students in some places, such asuniversity, high school, undergraduate students' hostel, school for the visually impaired, riverside village, and mall, using visual research methods.

An initial participative toilet design workshop was conducted in collaboration with $\mathrm{C} 2 \mathrm{O}$ Library and Ayorek!. It was conducted in small groups, guided by the lecturer, followed by resource persons, students, and common people. Hence, the workshop enriched the knowledge of inclusive design students.

The toilet design was developed by the students and lecturer, considering the five principles (compressed from the seven principles of universal design and three principles of inclusive design). The design was conducted within a month. To confirm the usability, a role-play using the design was conducted by suitable students.

A healthy toileting culture campaign program was conducted in the migrants' kampungs (villages) in riverside areas of Surabaya. The program was conducted by utilizing the video and comic produced by the initial program. After the socialization program another workshop was conducted to create a portable toilet design. The portable design responded to the context of urban's migrant context.

\section{Results and discussion}

The Kampung Bratang Baru could possibly be themost obvious example of the informal migrant Kampung. The Kampung was created by the informal land lords in 2001 by reclaiming the riverside areas. The area was initially allocated for urban scavengers (pemulung), but later was converted in 2002 into the urban migrants' homes, because of the scavengers' temporary living nature. The area was built from temporary and recycled materials such as wood, plywood, zinc, asbestos etc.

Because of the anxiety of the eviction at the adjacent riverside kampungs, residents of Kampung Bratang Baru joined the JERIT (Jaringan Rakyat Tertindas or Oppressed People Network) organization in 2002. JERIT is the name of the Non-Governmental Organisation assisting four groups such as PPTS (Paguyuban Pembela Tanah Strenkali or Riverside Community Rights Defenders), PKL/Pedagang Kaki Lima (the street vendors), PSK/Pekerja Seks Komersial (the sex workers) and Anak Gelandangan (the homeless street 
children). PPTS broke away from JERIT in February 2005 to become PWSS (Paguyuban Warga Strenkali Surabaya or Riverside Kampung Residents' Organisation).

Because of some riverside demolition incidents, residents of Kampung Bratang Baru withdrew from JERIT and joined the PWSS for stronger political support. After joining the PWSS, they started to reorganize their Kampungs, adopting PWSS' concept of "Jogo Kali" ("Defend the River"). The concept is implemented through rebuilding/renovating their homes so it become face-to-face with the river, while improving the Kampung's socialeconomical-environmental condition. It turned out that the progress of the renovation were relatively slow, and Kampung Bratang Baru must faced two partial demolitions during 2005 to 2006. Fortunately, they succeeded to stop the demolition by PWSS's rally and legal advocacy to the government. After that, they started rebuilding the demolished part of the Kampung. They showed great resistance of the urban migrants.

Finally in 2007, they accepted their partial legal protection from the Peraturan Daerah no 9 tahun 2007 tentang Penataan Pemukiman di Sempadan Kali Surabaya dan Kali Wonokromo (Provincial Regulation number 2007, on Riverside Settlement Renovation in Surabaya's River and Wonokromo's River). The regulation actually allowed the Riverside Kampung of Surabaya to exist but only for limited settlements. The people of Riverside Kampung could have a right to live there, taking up the role to take care the river and not to construct more homes. Furthermore, they have to prepare both open public spaces and green spaces. With the partial legal recognition, the people of Kampung Bratang Baru has continued to renovate their Kampung especially its infrastructures.

The need of proper bathing-washing-toileting facility is the main priority of the residents of Kampung Bratang Baru. They usually used the river for bathing, washing and toileting. This practice actually was driven because of the lack of clean water supply, limited economic capacity as well as their original rural toileting behavior. The UNDK Petra (University Network of Digital Knowledge of Petra University) collaborated with PWSS in 2013 to document the toileting culture in Riverside Kampungs including the Kampung Bratang Baru. [1] A portable toilet design was proposed to answer the migrating pattern of the people as well as the limited economic condition of them. Design of the toilet was produced during the Healthy Toileting Campaign in several Riverside Kampungs, including Kampung Bratang Baru. The toilet was reviewed and discussed in the meeting with lecturers and students from Petra University and residents of Kampung Bratang Baru, in June 2014.
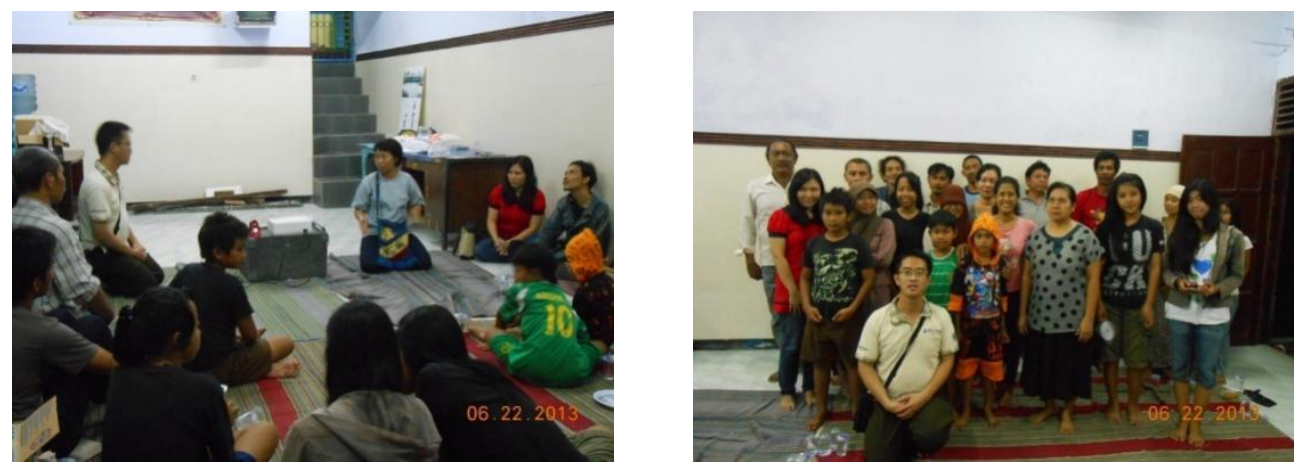

Fig. 1. The healthy toileting campaign in riverside villages.

The portable toilet design in Kampung Bratang Baru was proposed using the recycled steel scaffolding that commonly found in the urban area. The scaffolding is covered with cement-based board - framed with wood that could resist the water splash of the bathing and washing activities. The toilet was also provided from recycled toilet. Meanwhile, a clean water tank is going to be proposed for water provision, supplied by clean water 
pipeline and rainwater harvesting. And the bio septic tank (from fiber resin) is going to be provided for processing the feces and dirty water.

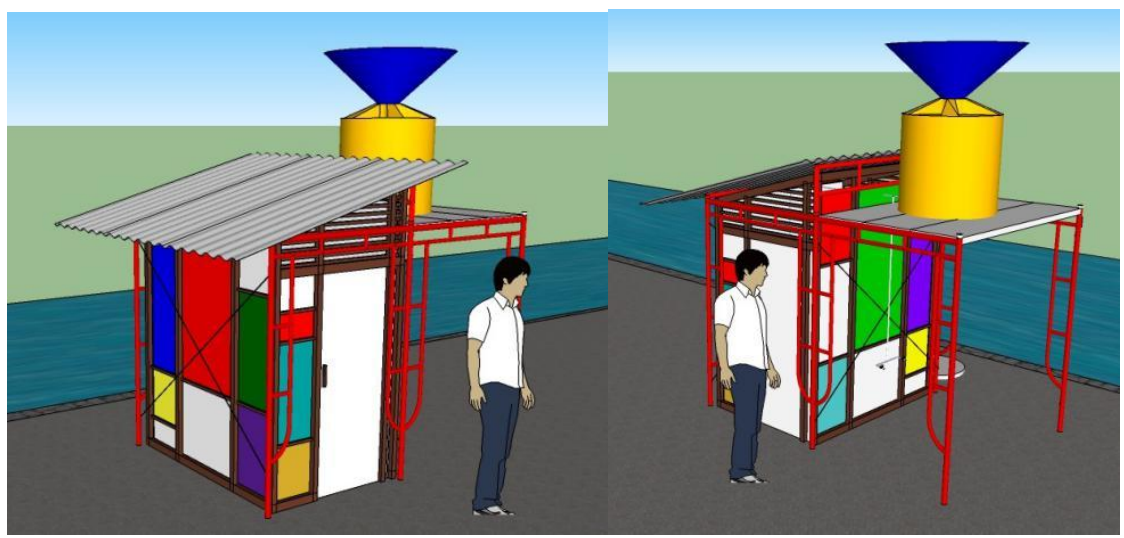

Fig. 2. The portable toilet design for urban migrants' kampung.

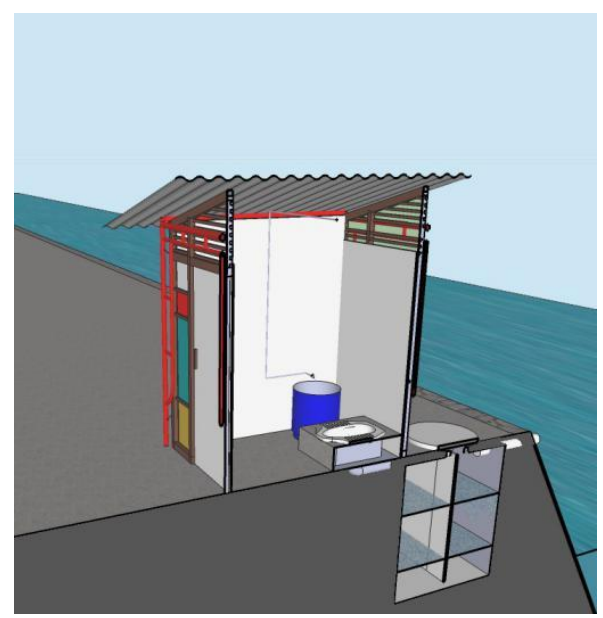

Fig. 3. The sectional-perspective of the portable toilet design for urban migrants' kampung.

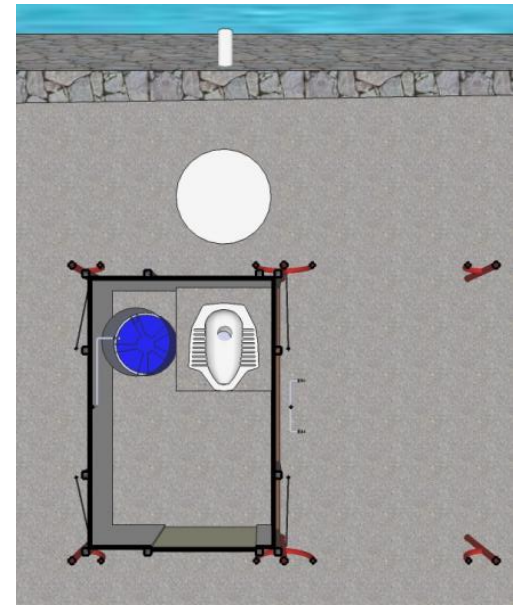

Fig. 4. The plan of the portable toilet design for urban migrants' kampung. 


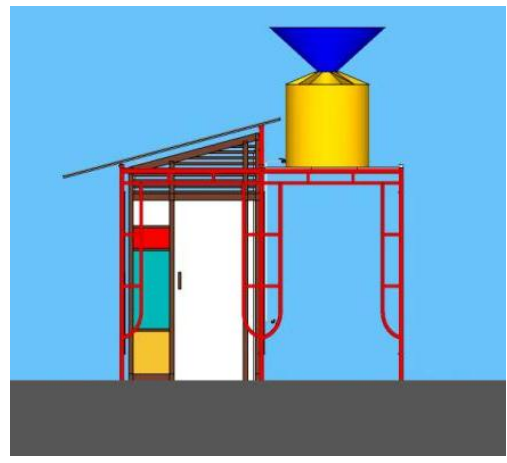

Fig. 8. The front elevation of the portable toilet design for urban migrants' kampung.

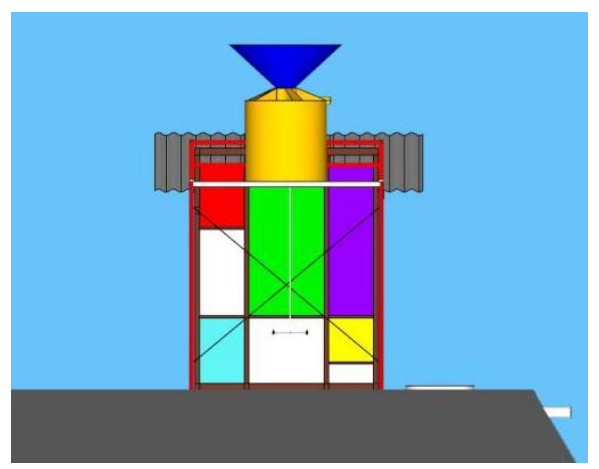

Fig. 9. The side elevation of the portable toilet design for urban migrants' kampung.

The design was proposed to private companies to be supported by them. Unfortunately, because of the limited funding and illegal land status, the project was cancelled to continue. The Bratang Baru Village was later on evicted by the Government in 2016 because ofaesthetic reason.

\section{Conclusion}

The future vision of Kampung Bratang Baru is to create a healthier Riverside Kampung, supported by water-related tourism, creative small-scale recycling industry and creative art performances. The migrants of Kampung Bratang Baru would like to improve their living condition especially the toilets and would like to have a full legal protection for their lands. They also hope that urban migrants were taken care and treated just like any other Surabaya's inhabitants, not being afraid by the demolitions of the Kampung anymore. As well as they hope the city could provide creative facilities to support their livelihoods such as traditional markets, informal open spaces, tricycle and bicycle pathways, etc.

The authors would like to thank:

i) Avron Boretz Ph.D. (Former Representative of United Boards, Hongkong).

ii) Prof. Ir. Rolly Intan, M.A.Sc., Dr.Eng (Rector of PCU).

iii) Prof. Budi Widianarko (Rector of Soegijapranata Catholic University 2009-2013).

iv) Ir. Hanny Hosiana Tumbelaka, M.Sc., Ph.D (1st Vice Rector of PCU 2009-2013).

v) Prof. Ir. Djwantoro Hardjito, M.Eng., Ph.D. (1st Vice Rector of PCU 2013 - 2017).

vi) Dr. Bernadeta Soedarini (Soegijapranata Catholic University, Director of UNDK Indonesia).

vii) Liauw Toong Tjiek, S.T., M.S. PhD. cand. [Aditya Nugraha] (The Head of Petra Library and Board of UNDK May 2013 - March 2014).

viii) Agus Dwi Hariyanto, S.T., M.Sc. (The Head of Architecture Program 2009-2013). 
ix) Other The UNDK Petra team: Meilinda, S.S., M.A., Heru Dwi W., M.Pd. , Aniendya Christianna S.Sn., Budi Prasetyadi, S.Sn . and Stefanny Irawan, S.S., MA.

x) Surabaya Riverside-Villages' Residents Association (PWSS/ Paguyuban Warga Strenkali Surabaya).

xi) Service Learning Course C - Inclusive Design Students of Odd Semester in 2013-2014.

xii) C2O Library

xiii) Ayorek! Platform

xiv) YPAB Blind School (SMP-LB YPAB School)

xv) Tutus Setiawan, S.Pd.

xvi) Ahmad Fauzi M..Hum.

\section{References}

1. G. Tanuwidjaja, Meilinda, E. Srisanto, H.D. Waluyo, O.B. Wicandra, A. Christianna, et al. final report portraying the toileting culture of Surabaya people: people perception and toilet design diversity [Online] from https://www.scribd.com/doc/194340096/PORTRAYING-THE-TOILETINGCULTURE-OF-SURABAYA-PEOPLE-Main-Report (2013). [Accessed on 3 December 2017]

2. H. Persson, H. Åhman, A.A. Yngling, J. Gulliksen. Universal Access in the Information Society, 14, (4):505-526 (2015). https://ink.springer.com/article/10.1007/s10209-014-0358-z

3. C. Bühler. Universal Access in the Information Society, 1, 2:85-90, (2001). https://link.springer.com/article/10.1007/s102090100011

4. A. Pirinen. International Journal of Design, 10, 3:27-42 (2016). http://www.ijdesign.org/index.php/IJDesign/article/view/2575

5. C. Greed. Inclusive urban design: public toilets. Oxford: Elsevier (2003). http://eprints.uwe.ac.uk/6049/

6. P.F. Lanjouw, M.P. Pradhan, F. Saadah, H. Sayed, R.A. Sparrow. Poverty, education, and health in Indonesia: who benefits from public spending? [Online] from http://documents.worldbank.org/curated/en/349171468771677180/Poverty-educationand-health-in-Indonesia-who-benefits-from-public-spending (2001). [Accessed on 11 December 2017]

7. K.W. Michael. The Journal of the Royal Society for the Promotion of Health, 128, 6:313-319 (2008).

http://journals.sagepub.com/doi/abs/10.1177/1466424008092801?journalCode=rshe

8. W. Cummings. Journal of Mundane Behavior, 1, 3, 261-273 (2003).

9. H. Factura, T. Bettendorf, C. Buzie, H. Pieplow, J. Reckin, R. Otterpohl. Water Science and Technology, 61, 10:2673-2679 (2010). https://www.ncbi.nlm.nih.gov/pubmed/20453341

10. K. Kindstedt. Design of a portable ecological sanitation toilet for disaster relief [Online] from www.sswrm.info $>$ reference attachments (2012). [Accessed on 3 December 2017] 